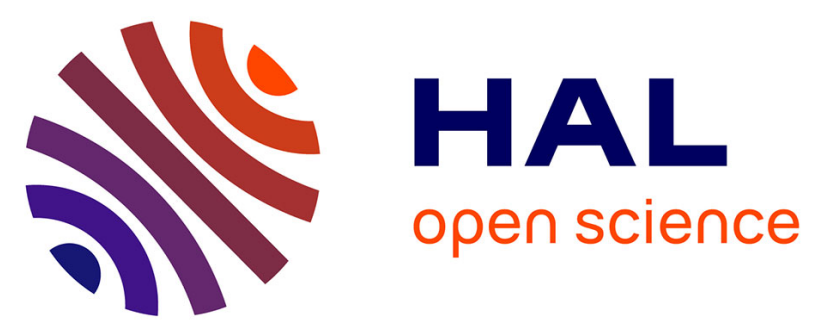

\title{
In-situ 3D investigation by fast X-Ray microtomography of the microstructural changes occurring during partial remelting of Al-Cu alloys
}

\author{
Michel Suery, Luc Salvo, Charles Josserond, Marco Di Michiel
}

\section{To cite this version:}

Michel Suery, Luc Salvo, Charles Josserond, Marco Di Michiel. In-situ 3D investigation by fast XRay microtomography of the microstructural changes occurring during partial remelting of $\mathrm{Al}-\mathrm{Cu}$ alloys. S2P9, 2006, Busan, South Korea. pp.231-234, 10.4028/www.scientific.net/SSP.116-117.231 . hal-00148255

\section{HAL Id: hal-00148255 \\ https://hal.science/hal-00148255}

Submitted on 15 Sep 2021

HAL is a multi-disciplinary open access archive for the deposit and dissemination of scientific research documents, whether they are published or not. The documents may come from teaching and research institutions in France or abroad, or from public or private research centers.
L'archive ouverte pluridisciplinaire HAL, est destinée au dépôt et à la diffusion de documents scientifiques de niveau recherche, publiés ou non, émanant des établissements d'enseignement et de recherche français ou étrangers, des laboratoires publics ou privés. 


\title{
In-situ 3D investigation by fast X-Ray microtomography of the microstructural changes occurring during partial remelting of $\mathrm{Al}-\mathrm{Cu}$ alloys
}

\author{
Michel Suéry ${ }^{1, a}$, Luc Salvo ${ }^{1, b}$, Charles Josserond $^{1, \mathrm{c}}$ and Marco Di Michiel ${ }^{2, \mathrm{~d}}$ \\ ${ }^{1}$ Institut National Polytechnique de Grenoble, Génie Physique et Mécanique des Matériaux (GPM2), \\ UMR CNRS 5010, ENSPG, BP 46, 38402 Saint-Martin d'Hères Cedex, France \\ ${ }^{2}$ ESRF, BP 220, 38043 Grenoble Cedex, France \\ a'Michel.Suery@gpm2.inpg.fr, 'Luc.Salvo@gpm2.inpg.fr, 'Charles.Josserond@gpm2.inpg.fr, \\ dimichie@esrf.fr
}

Keywords: X-Ray microtomography, microstructure, Al-Cu alloys, partial remelting

\begin{abstract}
The evolution of the microstructure of semi-solid Al-Cu alloys has been characterized during isothermal treatments in the semi-solid state by using in-situ X-ray microtomography experiments carried out at ESRF, Grenoble. This work is therefore a continuation of previous experiments reported at the $8^{\text {th }}$ S2P Conference in Limassol. Quantitative data are presented dealing with changes with holding time of the solid volume fraction, of the solid-liquid interface area and of the mean and Gaussian curvatures of the solid phase. Discussion of the results is carried out on the basis of the mechanisms involved in semi-solid systems.
\end{abstract}

\section{Introduction}

The microstructure of semi-solid alloys is usually characterized in polished sections at room temperature after quenching assuming that solidification of the liquid existing in the semi-solid state does not change too much the morphology of the solid phase. It has been shown, however, that, in the case of $\mathrm{Al}-\mathrm{Cu}$ alloys, the cooling rate must be higher than about $150 \mathrm{~K} / \mathrm{s}$ to freeze the initial microstructure [1]. Such cooling rates can be achieved in very small specimens only so that in many situations, the observation at room temperature does not accurately reflect the solid/liquid microstructure. In addition, 2D observations are usually not sufficient to fully characterize the microstructure. Serial sectioning has been applied [2] but this procedure is very difficult to carry out in a proper manner and it is time-consuming.

X-ray microtomography has been used quite extensively to obtain 3D microstructural information thanks to synchrotron radiation which permits high resolution of less than one micron. Characterization of globule connectivity and liquid entrapped in the globules has been thus carried out together with observations of shape change of solid particles during isothermal treatment in the semi-solid state [3, 4]. However, these observations required to quench the sample after each thermal treatment in order to perform the tomography scans at room temperature, so that it is quite difficult to find again the observed zone of the specimen. In addition, as indicated previously, changes of the microstructure can occur during quenching.

Recently, fast tomography was made possible thanks to high speed camera so that real in-situ scans could be performed during the thermal treatment of the sample without quenching it to room temperature. With this technique, characterization of the evolution of the microstructure of $\mathrm{Al}-\mathrm{Cu}$ alloys during holding in the semi-solid state was carried out and preliminary results were presented at the $8^{\text {th }}$ S2P Conference in Limassol [5]. In particular, the variations of the size of the globules and of the area of the solid-liquid interfaces were reported as a function of the holding time. In addition, comparison between values of the parameters before and after quenching confirmed that the characterization of the microstructure must be carried out in the semi-solid state for proper determination of the parameters. Some additional results dealing with the variation with holding time 
of the mean local curvature of the solid phase were presented later at the $2^{\text {nd }}$ International Light Metals Technology Conference 2005, St. Wolfgang, Austria [6].

The aim of this paper is to present some more results obtained by fast X-Ray tomography carried out during holding of Al-Cu alloys in the semi-solid state.

\section{Results and discussion}

The experiments were carried out with an $\mathrm{Al}-15.8 \mathrm{wt} \% \mathrm{Cu}$ alloy which was first solidified in a metallic mould in order to obtain a fine starting microstructure. X-Ray microtomography experiments were carried out at the ESRF Grenoble. The details of the experimental device and procedure have been given previously [5]. It is important to remind that the spatial resolution is about $3 \mu \mathrm{m}$ and the acquisition time for a full scan is about $15 \mathrm{~s}$. This allows performing in-situ microtomography during holding of the alloy in the semi-solid state since there is negligible evolution of the microstructure during such a short imaging time.

Fig. 1 shows the variation of the solid volume fraction in the specimen with holding time at a temperature of $555^{\circ} \mathrm{C}$. The solid fraction increases initially and then stabilizes at a value close to 0.68 . This variation is similar to that presented previously [5], but, for these experiments, much more measurements were carried out. The initial increase of the solid fraction is attributed to the progressive return of the specimen to thermodynamic equilibrium. The saturation value of $f_{s}$ is slightly larger than that given by the phase diagram for this alloy at $555^{\circ} \mathrm{C}$, which might be due to both to image analysis problems and temperature accuracy during the experiments.

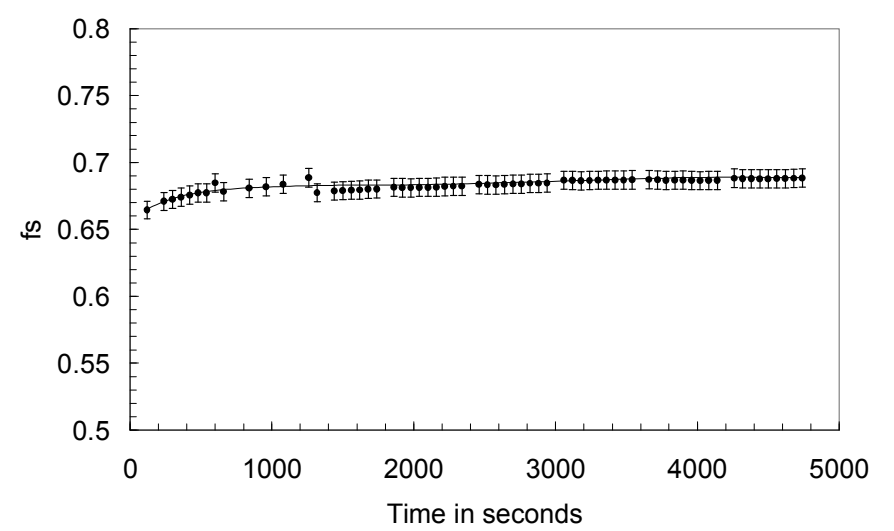

Figure 1: Variation of solid fraction with holding time at $555^{\circ} \mathrm{C}$

Fig. 2 shows the variation with holding time $t$ of the specific area of the solid-liquid interface $S_{v}$ normalized by its initial value $S_{\mathrm{v} 0}$. Again, this curve is very similar to that presented previously [5] which confirms that $\mathrm{Sv}$ decreases with increasing holding time in the semi-solid state. This variation can be written as:

$$
\mathrm{S}_{\mathrm{v}} / \mathrm{S}_{\mathrm{v} 0}=1.92 \mathrm{t}^{-0.127}
$$

which is very different from the usually reported variation $\left(S_{v} / S_{v 0}\right.$ proportional to $\left.t^{-1 / 3}\right)$.

This variation is compared to experimental data obtained by Wilson and coworkers on $\mathrm{Al}-\mathrm{Cu}$ alloys of various compositions [7] (Fig. 3). Obviously, these data were obtained on 2D sections of specimens quenched after holding in the semi-solid state. It is shown that the exponent is very dependent on the alloy composition and solid volume fraction and values close to that found in the tomography experiments have been also reported. 


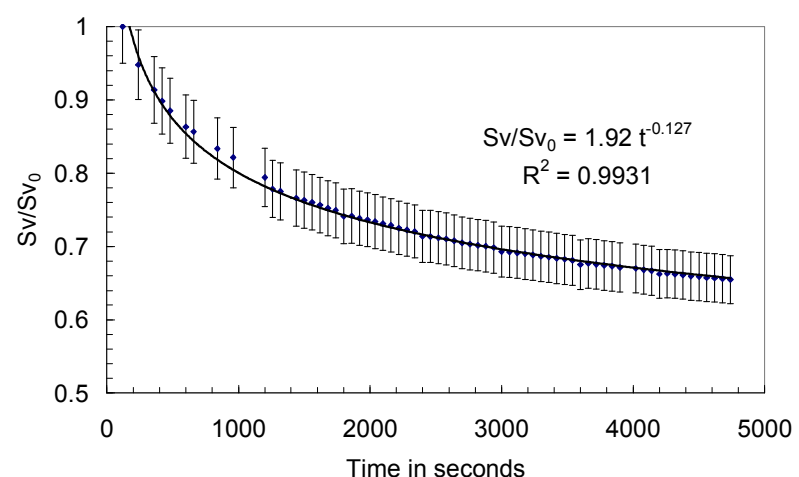

Fig. 2: Variation of the area of the solid-liquid interface (normalized by its initial value) with holding time in the semi-solid state.

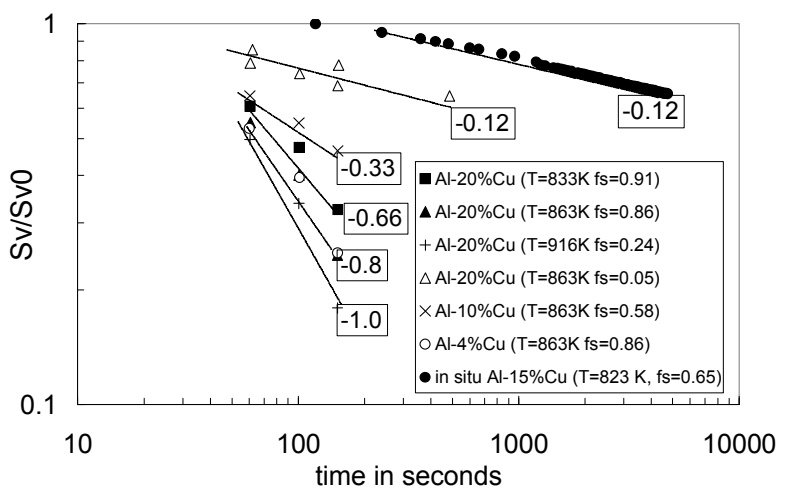

Fig. 3: Data from the literature in comparison with tomography deduced data for the variation of the area of the solid-liquid interface (normalized by its initial value) with holding time [7].

In order to characterise the evolution of the morphology of the solid phase during holding in the semi-solid state, the local mean and Gaussian curvatures of this phase were determined at various times. The mean and Gaussian curvatures $H$ and $K$ are defined as: $H=0.5\left(1 / R_{1}+1 / R_{2}\right)$ and $K=1 / R_{1}$ $x 1 / R_{2}$ where $R_{1}$ and $R_{2}$ are the two principal radii of curvature at any point of the solid phase. These parameters can be obtained by a method involving triangulating the surface and approximating this surface locally by a quadric form. One way of representation suggested by [8] is to plot $\mathrm{K}$ as a function of $\mathrm{H}$. In this plot, there is no data above the $\mathrm{H}^{2}-\mathrm{K}=0$ line. Various solid shapes correspond to the various regions in the H-K diagram (Fig. 4). In order to get an idea of the change of the solid morphology during holding, $\mathrm{H}$ and $\mathrm{K}$ were calculated for each holding time and probability density plots of $\mathrm{H}$ and $\mathrm{K}$ were obtained. Fig. 5 shows such a probability density plot for a holding time of 4 minutes: the brighter the region is, the higher the probability density is.

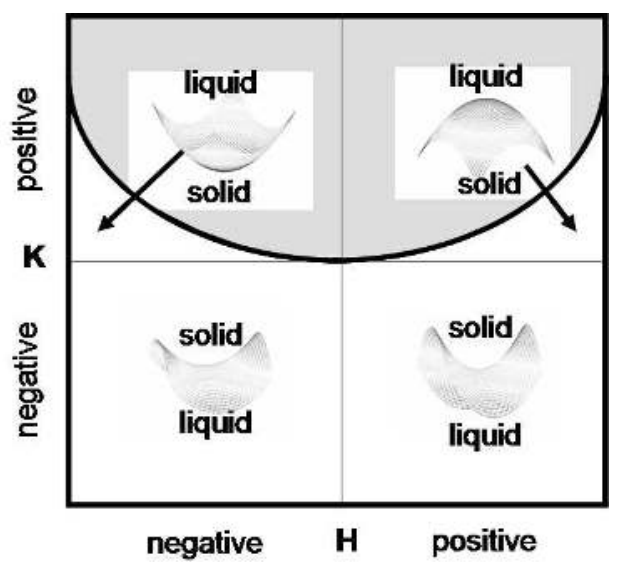

Fig. 4: Map of the various local interfacial shapes in the H-K diagram.

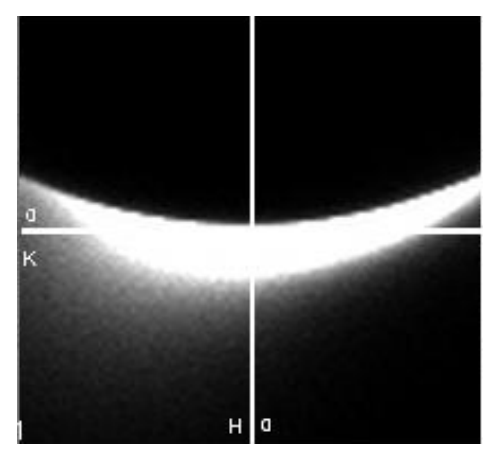

Fig. 5: Probability density plots of $\mathrm{H}$ and $\mathrm{K}$ for the specimen held for 4 minutes at $\mathrm{T}=555^{\circ} \mathrm{C}$

Fig. 6 shows the probability density plots of $\mathrm{H}$ and $\mathrm{K}$ for various holding times at $555^{\circ} \mathrm{C}$ and corresponding 2D sections of the specimen. Evolution of the plots takes place rapidly at the beginning and then stabilizes. This is consistent with the observations: spherodization of the globules occurs at the very beginning and then the evolution consists mainly in the coarsening of these globules. Nevertheless, it is to be noted that a great proportion of solid surfaces remain in the $\mathrm{H}<0$ and $\mathrm{K}<0$ region which corresponds to saddle-shape solid particles. This reflects probably the coalescence of the solid globules with increasing holding time since coalescence will involve formation and growth of necks between the globules. 

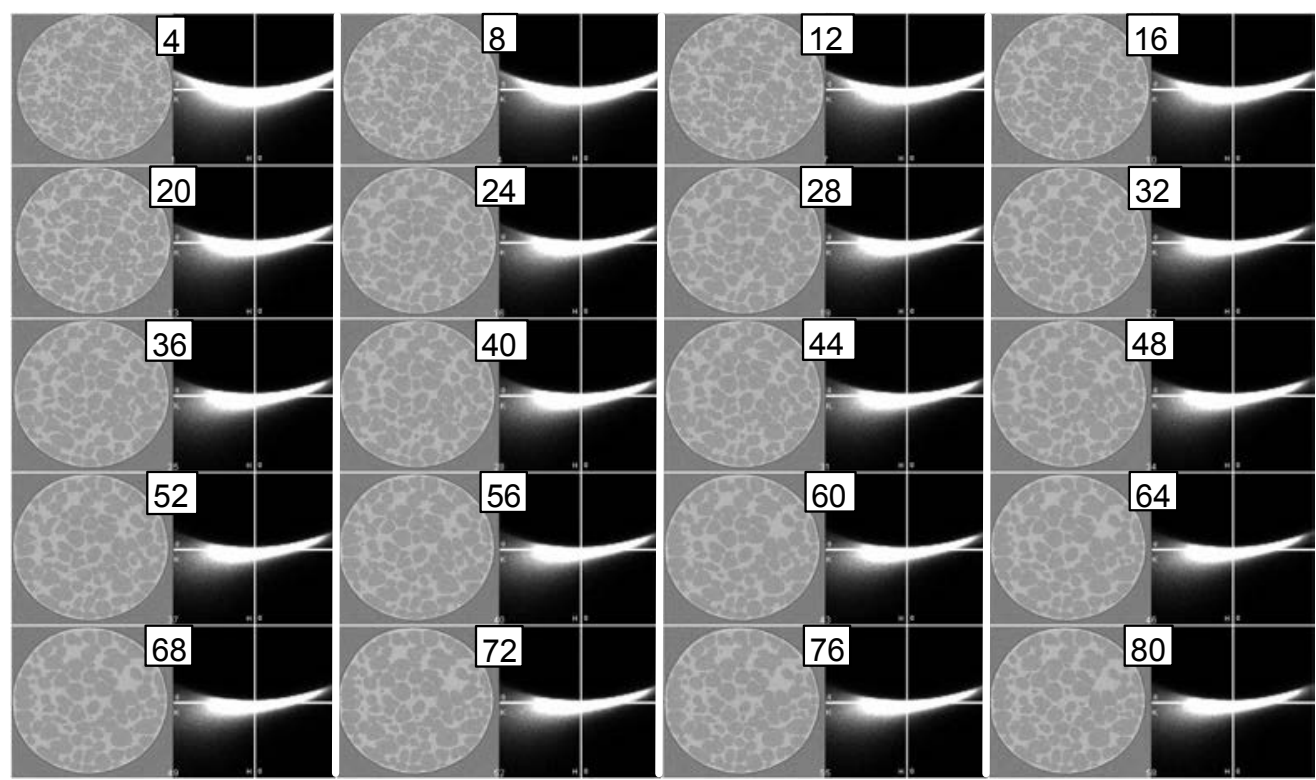

Figure 6: Probability density plots of $\mathrm{H}$ and $\mathrm{K}$ for various holding times and corresponding 2D sections. The numbers refer to the holding time (in min) at $555^{\circ} \mathrm{C}$.

\section{Conclusion}

In-situ X-Ray tomography allows characterizing the evolution of the microstructure of semi-solid alloys during holding time at high temperature and determining representative parameters of this microstructure. Variations of solid volume fraction and area of the solid liquid interfaces have been determined and plotted as a function of holding time. In particular, this area was found to decrease with increasing time in a way which is different from that usually reported. Other results concerning the local mean and Gaussian curvatures of the solid phase have been obtained allowing better understanding of the structural evolutions.

\section{References}

[1] O. Pompe and M. Rettenmayr: J. Crystal Growth, Vol. 192 (1998), p. 300

[2] J. Alkemper and P.W. Voorhees: Acta Mater., Vol. 49 (2001), p. 897

[3] S. Verrier, M. Braccini, C. Josserond, L. Salvo, M. Suéy, P. Cloetens and W. Ludwig: Proc. 6th Int. Conf. on Semi-solid Processing of Alloys and Composites, Turin, Sept. 27-29, 2000, Eds. G.L. Chiarmetta and M. Rosso, Edimet, Brescia, (2000), p. 771

[4] L. Salvo, M. Suéry, C. Josserond, P. Cloetens and Ø. Nielsen: Proc. of 7th S2P Conf. on Advanced Semi-solid Processing of Alloys and Composite, Tsukuba, Sept. 25-27, 2002, Eds. Y. Tsutsui, M. Kiuchi, K. Ichikawa, (2002), p. 403

[5] O. Ludwig, M. DiMichiel, P. Falus, L. Salvo and M. Suéry: $8^{\text {th }}$ S2P Conf. on Semi-solid Processing of Alloys and Composites, Limassol, Cyprus, 21-23 Sept. 2004, published as CD-ROM by NADCA, USA, 2004

[6] L. Salvo, M. Pana, M. Suéry, M. DiMichiel, Ø. Nielsen and D. Bernard: Proc. of $2^{\text {nd }}$ Int. Light Metals Tech. Conf, St. Wolfgang, Austria, . 8-10 June 2005, Ed. H. Kaufmann, LKR, (2005), p. 209

[7] P.W. Wilson, T.Z. Kattamis and Y. Shiohara: J. Mat. Science, Vol. 23 (1988), p. 2882

[8] R. Mendoza, J. Alkemper and P.W. Voorhees: Met. Mat. Trans. Vol. 34A (2003), p. 481 